\title{
Portrait of Transcriptional Expression Profiles Displayed by Different Glioblastoma Cell Lines
}

\author{
Paulo R. D. V. Godoy et al. ${ }^{1}$ \\ University of São Paulo, \\ Brazil
}

\section{Introduction}

Glioblastoma multiforme (GBM) is among the most lethal of all human tumors, with the average survival of approximately 1 year from diagnosis (Avgeropoulos and Batchelor, 1999). In glioblastomas, $\mathrm{LOH} 10 \mathrm{q}$ is the most frequent genetic alteration (69\%), followed by EGFR amplification (34\%), TP53 mutations (31\%), p16INK4a deletion (31\%), and PTEN mutations (24\%)(Ohgaki and Kleihues, 2005).

Treatments of patients with GBM include surgery, radiotherapy and parallel adjuvant chemotherapy (Stupp et al., 2005). While radiotherapy has been found to significantly prolong survival rates for GBM patients, a poor prognosis and radioresistance are typical characteristics of this disease (Stupp et al., 2007).

The antitumoral drug Temozolomide (TMZ) constitutes, in combination with radiotherapy, the current standard of care for glioblastoma (Stupp et al., 2005). However, the action of TMZ may be counteracted in tumors by the expression of the DNA repair enzyme MGMT, which repairs TMZ-induced DNA lesions (Hegi et al., 2005). MGMT activity and resistance to TMZ were highly correlated, indicating that MGMT is a major predictor of response to TMZ in glioma cells (Hermisson et al., 2006). According to the authors, collectively, MGMT expression and TP53 status may become valuable parameters to predict cell responses to TMZ treatment in patients with GBM. Modulation of MSH6, PARP1 and NTL1, DNA repair genes involved in mismatch repair and base excision repair (BER), were found at transcription and protein levels in GBM cells resistant to TMZ (Zhang et al., 2010).

Other genotoxic agents exert different effects in GBM cells with different TP53 status. UV light (UV-C) (Batista et al., 2009) and chloroethylating agents (ACNU and BCNU) (Batista et al., 2007), significantly induce apoptosis in TP53-mutated glioma cells, while WT TP53 cells are more sensitive to methylating agents, including TMZ (Hermisson et al., 2006; Roos et al., 2007).

Efforts have been made to overcome drug and radio-resistance of GBM cells, but the heterogeneity of these tumors seems to be critical, and molecular analysis is an important tool to elucidate the mechanisms underlying cellular responses to antitumoral agents. Recently, application of genome-scale methodologies has opened the opportunity to study

\footnotetext{
${ }^{1}$ Stephano S. Mello, Daniele A. Magalhães, Flavia S. Donaires, Ana P. Lima-Montaldi, Patricia Nicolucci, Eduardo A. Donadi, Geraldo A. S. Passos and Elza T. Sakamoto-Hojo
} 
transcript profiles for thousands of genes simultaneously, thus providing a picture on how different biological processes can be modulated under irradiation, drug treatment or even between different cell types, on the basis of the lists of differentially expressed genes (either induced or repressed genes) provided by the microarray experiments. This approach allows comparisons between different biological situations (Tusher et al., 2001; Sakamoto-Hojo et al., 2003; Fachin et al., 2007; Fachin et al., 2009). In a previous work, several stress response/DNA repair genes, such as HSPA9B, INPP5A, PIP5K1A, FANCG, and TPP2 were found up-regulated in U343MG-a GBM cells analyzed at $6 \mathrm{~h}$ following irradiation with $1 \mathrm{~Gy}$, reflecting the radio-resistance of these cells; at this condition, the survival rate was $61 \%$, and a broad spectrum of other biological processes was found associated to the list of differentially expressed genes in irradiated cells (Bassi et al., 2008).

TP53 gene plays a role in drug and radioresistance mechanisms, but the complex network of signaling pathways involving this gene is not well elucidated. TP53 is a multifunctional protein that acts in cell cycle blockage and signaling pathways towards DNA repair, contributing to the maintenance of genome integrity in response to a variety of genotoxic stresses (Bartussek et al., 1999). Alternatively, TP53 protein triggers a cascade of signaling pathways culminating in apoptosis, depending on the extent of DNA damage (Prise et al., 2005). The TP53 protein is also a transcription factor that regulates the expression of a large number of target genes (Vogelstein et al., 2000). Many TP53 target genes have been described (el-Deiry, 1998; Horn and Vousden, 2007; Laptenko and Prives, 2006; Sbisa et al., 2007), and some other targets have been computationally predicted by the analysis of their binding sites (Hoh et al., 2002; Smeenk et al., 2008; Veprintsev and Fersht, 2008).

According to the literature data, there are controversial findings about the outcome of patients in relation to the TP53 status of tumors; this gene may positive or negatively influences the cell radioresistance, as well as it can exert no influence in cellular responses to therapies (McIlwrath et al., 1994; Slichenmyer et al., 1993; Smith et al., 1995).

\section{Objective}

In the present work, we aim to compare gene expression profiles displayed by four GBM cell lines in the absence of any kind of treatment, using the microarray method, looking for molecular signatures that can provide new clues towards the understanding of GBM biology and radioresistance mechanisms. The results on the transcriptional profiles presented by a number of genes with different biological functions are discussed on the light of literature data regarding GBM cell responses to ionizing radiation and antitumor drugs, generally provided by survival assays.

\section{Materials and methods}

\subsection{GBM cell lines}

Human GBM U343 MG-a cell line was kindly donated by Dr. James T. Rutka (The Arthur and Sonia Labatt Brain Tumour Research Center, Canada), while T98G, U251MG, and U87MG were supplied by the American Type Culture Collection (ATCC) (Rockville, Maryland, USA). T98G and U251MG cell lines harbor three mutations (TP53, CDKN2A, and PTEN) while U343MG-a and U87MG cells are wild-type (WT) for TP53, and mutant (MT) for CDKN2A and PTEN genes (Ishii et al., 1999). 


\subsection{Cell culture and total RNA extraction}

For gene expression analysis, cells were thawed from the nitrogen and sub-cultured for four passages in the presence of HAM F10 + DEM medium plus 15\% fetal bovine serum and kept at $37^{\circ} \mathrm{C}$ and $5 \% \mathrm{CO}_{2}$. After the fourth sub-culturing, they were incubated for two days, and total RNA extraction was performed in replicate at $48 \mathrm{~h}$, by using the Trizol reagent (Invitrogen, Carlsbad, CA, USA) according to the manufacturer's instructions. The quality of RNA samples was evaluated by denaturing agarose gel electrophoresis under standard conditions. To remove the contaminating DNA, RNA samples used in cDNA microarrays were treated with the Deoxyribonuclease I (Amplification Grade kit, Invitrogen), according to manufacturer's instructions.

\section{3 cDNA microarray method}

Four experiments in duplicate using GBM cells were carried out using a glass slide microarray containing 4500 clones of cDNA probe (in duplicates) from the human IMAGE Consortium cDNA library [http://image.llnl.gov/image/; kindly provided by Dr. Catherine Nguyen (INSERM-CNRS, Marseille, France)], and prepared according to the protocol described by Hegde et al (2000).

Microarrays were spotted onto glass slides (Corning) using a Generation III Array Spotter Amersham-Molecular Dynamics according to the manufacturer's instructions. Each cDNA sample was spotted twice on the slide (duplicate spots). The cDNA complex probes were prepared using the CyScribe Post Labelling Kit (Amersham Biosciences, England) (Fachin et al., 2009). Hybridizations were carried out using an automatic system (Automatic Slide Processor, Amersham Biosciences, England) and signals were immediately captured after the final wash procedure, using a Generation III laser scanner (Amersham Biosciences, England).

In an attempt to characterize the clones present in the array slide, the gene set was submitted to the NIH-DAVID bioinformatic tool, in order to obtain biological functions associated with the gene sequences present in the arrays, as well as the number of genes associated with each biological process. Among all clones, 2334 were identified by official gene symbol (HUGO), distributed in classes according to biological processes (Table 1).

\subsubsection{Data acquisition and gene expression analysis}

The image quantification was performed using the Spot software, (http://spot.cmis.csiro.au/spot/, CSIRO, Australia). Filtering, normalization and data analysis were done using the $\mathrm{R}$ statistical environment (Ihaka and Gentleman, 1996), in addition to Limma (Smyth et al., 2005), Bioconductor (Ihaka and Gentleman, 1996), Aroma (Bengtsson, 2004) and KTH (Wirta, 2004). The background to each feature was subtracted from the foreground value. Furthermore, the spots were evaluated by their circularity and calculations on the median versus mean deviation, so that those presenting irregular circularity, or with large differences between mean and median values, were considered unreliable. The raw data (red $-\mathrm{R}$ and green $-\mathrm{G}$ ) was transformed into MA format before normalization, where $M=\log 2(R / G)$ and $A=1 / 2 \times \log 2(R \times G)$. These procedures were followed by the application of the Print-tip Lowess normalization for each slide. Following the normalization procedure, microarray data were exported to tab-delimited tables in MEV format and analyzed in MEV (v. 3.1) software (Saeed et al., 2003). The microarrays data analysis involved the application of the statistical method SAM - Significance Analysis of 


\begin{tabular}{|l|c|c|}
\hline GOTERM-BIOLOGICAL PROCESS - FAT & $\%$ & PValue \\
\hline GO:0007242 intracellular signaling cascade & 10.28 & $3.90 \mathrm{E}-09$ \\
\hline GO:0006793 phosphorus metabolic process & 9.43 & $8.50 \mathrm{E}-16$ \\
\hline GO:0006468 protein amino acid phosphorylation & 6.73 & $6.81 \mathrm{E}-13$ \\
\hline GO:0008104 protein localization & 6.68 & $2.00 \mathrm{E}-04$ \\
\hline GO:0042981 regulation of apoptosis & 6.47 & $1.20 \mathrm{E}-05$ \\
\hline GO:0007049 cell cycle & 5.96 & $2.63 \mathrm{E}-04$ \\
\hline GO:0033554 cellular response to stress & 5.78 & $1.27 \mathrm{E}-11$ \\
\hline GO:0006259 DNA metabolic process & 4.50 & $4.42 \mathrm{E}-06$ \\
\hline GO:0006974 Response to DNA damage stimulus & 4.07 & $5.32 \mathrm{E}-10$ \\
\hline GO:0006281 DNA repair & 3.43 & $8.95 \mathrm{E}-11$ \\
\hline GO:0007243 protein kinase cascade & 3.43 & $1.53 \mathrm{E}-05$ \\
\hline $\begin{array}{l}\text { GO:0007167 enzyme linked receptor protein } \\
\text { signaling pathway }\end{array}$ & 3.08 & $1.04 \mathrm{E}-04$ \\
\hline GO:0009314 response to radiation & 1.93 & $5.82 \mathrm{E}-04$ \\
\hline GO:0000165 MAPKKK cascade & 1.89 & $1.69 \mathrm{E}-04$ \\
\hline GO:0022604 regulation of cell morphogenesis & 1.41 & $4.85 \mathrm{E}-04$ \\
\hline GO:0006310 DNA recombination & 1.29 & $9.19 \mathrm{E}-05$ \\
\hline $\begin{array}{l}\text { GO:0031344 regulation of cell projection } \\
\text { organization }\end{array}$ & 1.11 & $2.05 \mathrm{E}-04$ \\
\hline GO:0006302 double-strand break repair & 0.94 & $3.35 \mathrm{E}-05$ \\
\hline GO:0006289 nucleotide-excision repair & 0.86 & $5.76 \mathrm{E}-05$ \\
\hline GO:0050770 regulation of axonogenesis & 0.81 & $3.26 \mathrm{E}-04$ \\
\hline GO:0051291 protein heterooligomerization & 0.77 & $2.99 \mathrm{E}-04$ \\
\hline GO:0050772 positive regulation of axonogenesis & 0.51 & $1.85 \mathrm{E}-04$ \\
\hline GO:0000723 telomere maintenance & 0.51 & $6.05 \mathrm{E}-04$ \\
\hline $\begin{array}{l}\text { GO:0032925 regulation of activin receptor } \\
\text { signaling pathway }\end{array}$ & 0.30 & $7.62 \mathrm{E}-04$ \\
\hline
\end{tabular}

Table 1. Percentage of genes for each biological process analyzed for a total of 2334 genes present in a glass slide microarray. The array gene set (containing 4300 image clones) was submitted to NIH-DAVID (Dennis et al. 2003).

Microarray (Tusher et al., 2001), with the objective to compare MT versus WT TP53 cell lines in terms of expression profiles. We used FDR $<0.68 \%$ to select only highly significant differentially expressed genes.

Information regarding biological functions were obtained at S.O.U.R.C.E. (http://genomewww5.stanford.edu/cgi-bin/SMD/source/source), and NCBI (http://www.ncbi. nlm.nih.gov/). Gene functional groups were given by DAVID tool (Dunne et al., 2003), 
choosing Homo sapiens as the current background, Gene Ontology: GOTERM_BP_FAT as parameters, and Functional Annotation Chart as the analyzing tool. The main biological functions associated to the list of differentially expressed genes were selected.

Every modulated gene was compared to a list of previously identified genes with TP53 binding sites using genome-wide tiling Chromatin immunoprecipitation (ChIP)-on-chip approach (Smeenk et al., 2008) or (ChIP) with the paired-end ditag (PET) (Wei et al., 2006) in order to point out genes that could be modulated by TP53 transactivation.

\section{Results}

\subsection{Transcript profiles displayed by GBM cell lines 4.1.1 Hierarchical cluster analysis}

Gene expression profiles studied by the cDNA microarray method generated interesting results about the transcriptional profiles exhibited by each cell line. Analysis of gene cluster uses standard statistical algorithms in order to arrange genes according to similarity of expression patterns, and the results can be graphically represented (Eisen et al., 1998). The analysis of hierarchical clustering was performed to compare MT and WT TP53 cells regarding transcript profiles by using a set of genes previously selected by the SAM analysis. The results of the hierarchical clustering showed that MT TP53 cells were grouped apart from the WT TP53 cells. The mutant cell lines (T98G and U251) were not separated within a gene cluster, indicating more similarity in the basal transcription levels between cell lines; in contrast, the proficient cell lines (U87 and U343) were clustered apart from each other (Fig.1).

\subsubsection{Differentially expressed genes indicated by Significant Analysis of Microarrays (SAM)}

The statistical analysis performed by SAM indicated that MT TP53 cell lines showed 29 down-regulated and 68 up-regulated genes, compared with WT TP53 cells, for FDR $\leq 0.68 \%$. For this small list of highly significant differentially expressed genes, the magnitude of foldchanges ranged from -1.68 to +1.93 by comparing MT versus WT TP53 (Supp. Table 1 ).

For the list of differentially expressed genes, biological gene functions were studied by the DAVID-NIH bioinformatic tool (Dennis et al., 2003; Huang da et al., 2009). Out of 97 modulated genes, 73 were suitable for functional grouping procedure, since 10 genes were not grouped and 14 I.D. clones were still unknown. The most relevant categories (represented by a variable number of genes) were related to neurological system process $(11 \%)$, regulation of apoptosis $(10 \%)$, cellular response to stress $(8 \%)$, regulation of cell proliferation (8\%), cell-cell adhesion (5\%), DNA repair $(5 \%)$, response to ionizing radiation $(4 \%)$, histone modification (4\%), cell division (4\%), etc. (Fig.2.). For discussion, we selected 36 genes on the basis of biological functions that can be possibly related to responses to genotoxic agents (Table-2), in order to find out clues for understanding the mechanisms underlying the sensitivity or resistance to anticancer therapies. Some of candidate genes that may participate in chemo- and/or radioresistance are involved in stress responses (RUVBL2, ASNS, RNF8, LIG4 and CAV1) and cell adhesion (CDH8, CDH13, CD93 and ITGA5), and other important cathegories, such as regulation of cell proliferation (IGF1R, CDH13, CAV1, DUSP22, ADAMTS1, LIG4) and apoptosis (IGF1R, CDH13, IFT57, CRH, HSPB1, ASNS and LIG4. 


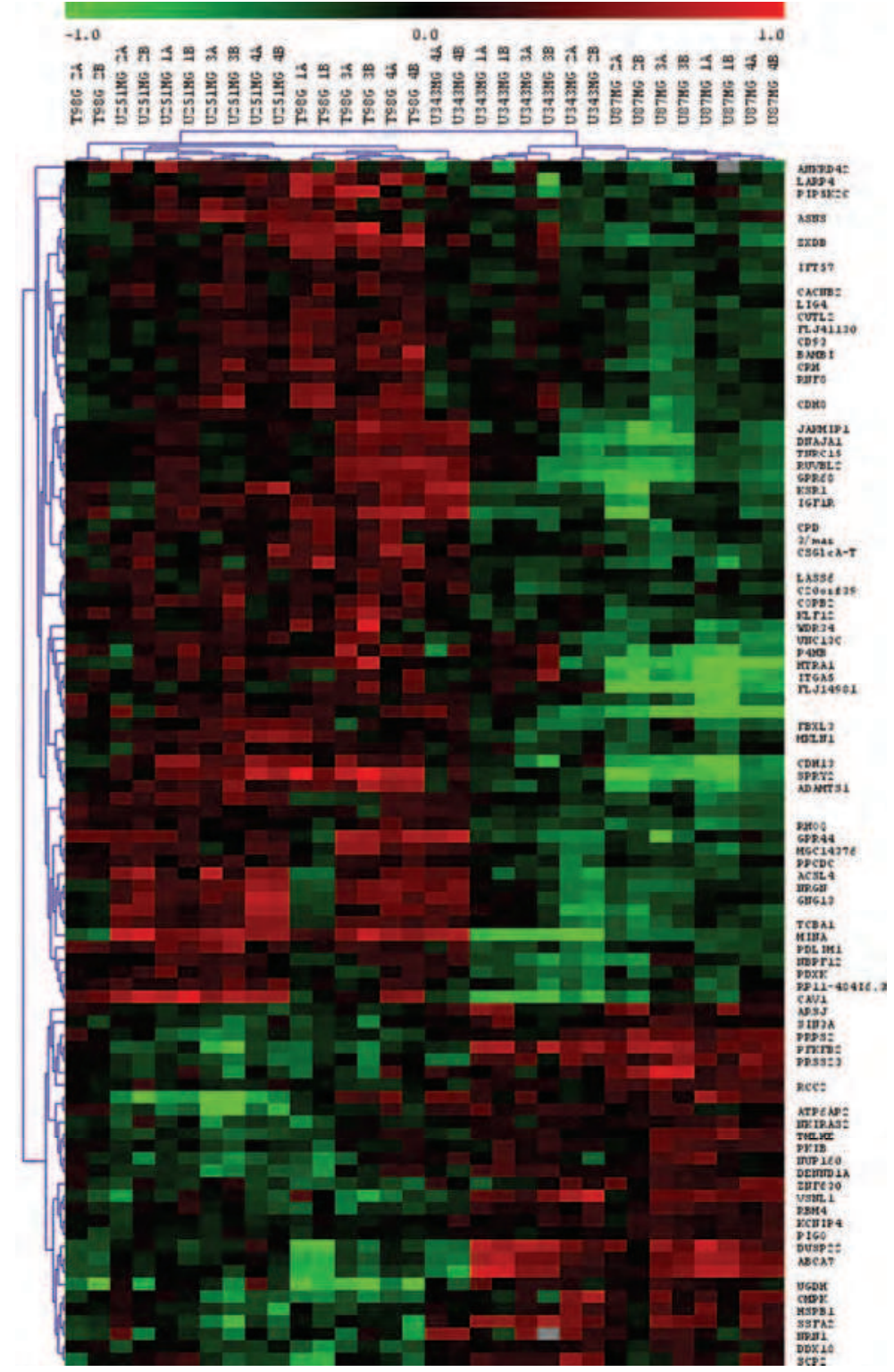

Fig. 1. Hierarchical clustering obtained for a gene set previously selected by the SAM method (FDR $\leq 0.68 \%$ ) for the results displayed by four GBM cell lines (T98G, U251MG, U343MG-a e U87MG), under normal proliferation in culture. The data set was provided by 4 experiments in duplicate. Experiments are represented by numbers (1-4) and the replicates are represented by letters (A and B). The expression level of each gene is represented according to the scale at the top (red indicates induction; green means repression; grey color represents data loss). 


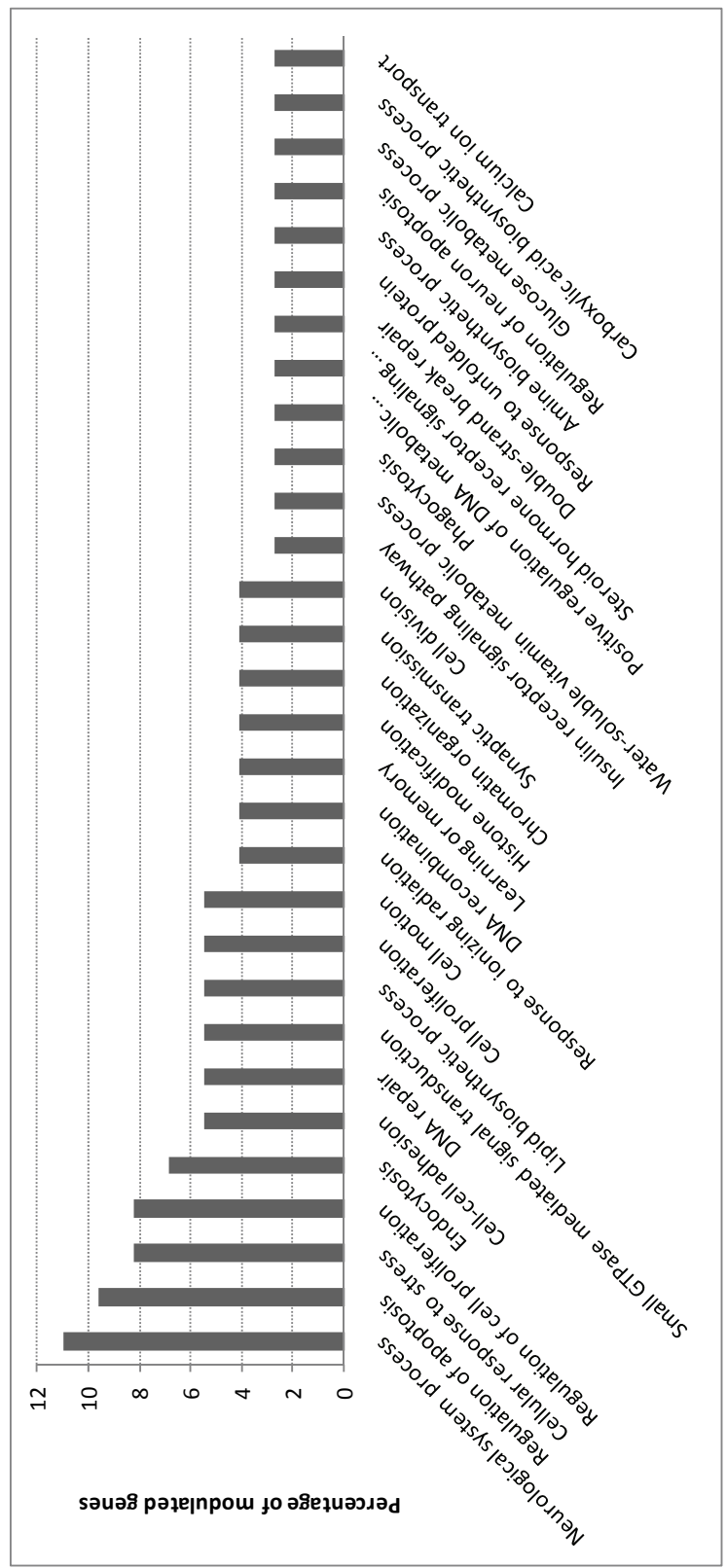

Fig. 2. Main Biological functions associated to the list of differentially expressed genes (out of 97 genes, 73 genes were recognized by the system) when comparing MT and WT TP53 GBM cell lines. The results were analyzed by DAVID-NIH (Dennis et al., 2003; Huang da et al., 2009) as a bioinformatic tool to group differentially expressed genes according to their functions. 
A comparative analysis of differentially expressed genes (obtained by SAM) was carried out with previously identified genes with TP53 binding sites using ChIP-PET and ChIP-on-chip analysis (Smeenk et al., 2008; Wei et al., 2006). When comparing with ChIP- PET gene lists, we observed only one common gene (LASS6), while the comparison involving the gene list of our work with the ChIP-on-chip list, we found five common genes (ARSJ, RCC2, CDH8, CDH13 and HTRA1).

\section{Discussion}

Expression profiles displayed by GBM cells provided results to compare these cells with other tumor types (Castells et al., 2010; Castells et al., 2009; Dreyfuss et al., 2009; Marucci et al., 2008; Reddy et al., 2008), normal tissues (Sallinen et al., 2000), or even regions in the same tumor (Mehrian Shai et al., 2005). However, there is no data in the literature comparing transcript profiles of GBM cell lines presenting similar genetic background. While T98G and U251MG harbor mutations for TP53, CDKN2A, and PTEN, U343MG-a and U87MG cell lines differ from others by the presence of a known WT TP53 (Ishii et al., 1999). Expression profiles displayed by GBM cell lines were studied in the absence of any treatment. The hierarchical clustering analysis compared WT and MT TP53 GBM cells regarding transcript profiles using a set of highly significant differentially expressed genes previously selected by SAM (FDR $\leq 0.68 \%$ ). The results showed distinct expression profiles for WT TP53 and MT TP53 cells, whose patterns separate the mutant from WT cells. The mutant cell lines (T98G and U251MG) were not completely separated from each other within the cluster, indicating similarity of transcript patterns between the two cell lines. In contrast, TP53 proficient cell lines (U87MG and U343MG-a) were clustered apart from each other. These results indicate the potential of the DNA microarray analysis to discriminate molecular profiles displayed by GBM cell lines presenting similar mutational background for CDKN2A and PTEN genes, but with different TP53 status.

The statistical analysis performed by SAM (FDR $\leq 0.68 \%$ ) indicated that MT TP53 cell lines showed 28 down-regulated and 66 up-regulated genes, when compared to WT TP53 cells (Table. 2). For the list of differentially expressed genes, biological gene functions were studied by the DAVID-NIH bioinformatic tool (Dennis et al., 2003; Huang da et al., 2009), and several biological processes were associated to the list of significant differentially expressed genes, such as: metabolism, response to ionizing radiation, cell adhesion, cell motion, apoptosis, DNA repair and transcription.

In addition, metabolic process was directly related with several biological functions as follow: insulin receptor signalling, water soluble vitamin metabolic process, steroid hormone receptor signalling, cellular response to nutrient levels, amine biosynthetic process, lipid biosynthetic process, calcium ion transport, lipid transport, glucose metabolic process, carboxylic acid biosynthetic process, and cellular amino acid derivative metabolic process. Other gene functions related to learning/memory, regulation of neuron apoptosis, synaptic transmission, and neurological system processes are intrinsic to the neural nature of GBM cells. DNA and RNA metabolism/regulation were also associated to several differentially expressed genes (Table. 2).

Three genes (RNF8, CAV1 and LIG4) playing roles in ionizing radiation responses were found up-regulated in MT TP53 cells, and this feature may influence the responsiveness to radiotherapy. It is already known that ionizing radiation causes DNA double-strand breaks (DSBs) that are highly cytotoxic lesions. Cells have a complex DNA-damage response that 


\begin{tabular}{|c|c|c|c|c|}
\hline Symbol & CloneID & Biological Process & $\begin{array}{l}\text { Fold } \\
\text { change }\end{array}$ & $\begin{array}{l}\text { q- } \\
\text { value } \\
(\%)\end{array}$ \\
\hline SPRY2 & 40262 & $\begin{array}{l}\text { cell-cell signaling, development, organogenesis, } \\
\text { regulation of signal transduction }\end{array}$ & 1.93 & 0.00 \\
\hline CAV1 & 24651 & $\begin{array}{l}\text { cellular calcium ion homeostasis, cholesterol efflux, } \\
\text { response to gamma radiation, regulation of apoptosis, }\end{array}$ & 1.86 & 0.00 \\
\hline $\mathrm{CDH} 13$ & 31093 & cell adhesion, homophilic cell adhesion & 1.61 & 0.00 \\
\hline HTRA1 & 132044 & proteolysis and peptidolysis, regulation of cell growth & 1.55 & 0.00 \\
\hline $\begin{array}{l}\text { ADAMT } \\
\quad \text { S1 }\end{array}$ & 34684 & $\begin{array}{l}\text { integrin-mediated signaling pathway, negative } \\
\text { regulation of cell proliferation, heart trabecula formation, } \\
\text { kidney development, ovulation from ovarian follicle, } \\
\text { proteolysis }\end{array}$ & 1.54 & 0.00 \\
\hline ITGA5 & 135671 & $\begin{array}{c}\text { cell-matrix adhesion, integrin-mediated signaling } \\
\text { pathway }\end{array}$ & 1.35 & 0.75 \\
\hline GPR68 & 22652 & $\begin{array}{l}\text { G-protein coupled receptor protein signaling pathway, } \\
\text { inflammatory response, signal transduction }\end{array}$ & 1.34 & 0.00 \\
\hline GPR44 & 25625 & $\begin{array}{c}\text { G-protein coupled receptor protein signaling pathway, } \\
\text { immune response, calcium-mediated signaling, } \\
\text { chemotaxis }\end{array}$ & 1.34 & 0.75 \\
\hline RUVBL2 & 22267 & $\begin{array}{l}\text { chromatin modification, DNA recombination, DNA } \\
\text { repair, regulation of growth, regulation of transcription }\end{array}$ & 1.33 & 0.00 \\
\hline MKLN1 & 33715 & cell motility, cell-matrix adhesion, signal transduction & 1.31 & 0.00 \\
\hline KSR1 & 220655 & $\begin{array}{l}\text { Ras protein signal transduction, intracellular signaling } \\
\text { cascade, protein amino acid phosphorylation }\end{array}$ & 1.31 & 0.75 \\
\hline GNG13 & 178213 & $\begin{array}{l}\text { G-protein coupled receptor protein signaling pathway, } \\
\text { signal transduction }\end{array}$ & 1.30 & 0.75 \\
\hline $\mathrm{CDH} 8$ & 38939 & cell adhesion, homophilic cell adhesion & 1.30 & 0.00 \\
\hline $\begin{array}{c}\text { DNAJA } \\
1\end{array}$ & 24473 & protein folding, response to unfolded protein & 1.28 & 0.75 \\
\hline RHOQ & 131061 & small GTPase mediated signal transduction & 1.26 & 0.00 \\
\hline FBXL3 & 25778 & protein ubiquitination & 1.26 & 0.00 \\
\hline $\mathrm{CRH}$ & 34671 & $\begin{array}{l}\text { immune response, learning and/or memory, pregnancy, } \\
\text { signal transduction, synaptic transmission }\end{array}$ & 1.24 & 0.00 \\
\hline IGF1R & 21519 & $\begin{array}{c}\text { axonogenesis, brain development, exocrine pancreas } \\
\text { development, male sex determination, regulation of } \\
\text { apoptosis }\end{array}$ & 1.24 & 0.00 \\
\hline ASNS & 27208 & amino acid biosynthesis & 1.23 & 0.90 \\
\hline CD93 & 35503 & cell-cell adhesion, macrophage activation, phagocytosis & 1.19 & 0.00 \\
\hline COPB2 & 24627 & $\begin{array}{c}\text { intracellular protein transport, vesicle-mediated } \\
\text { transport }\end{array}$ & 1.18 & 0.00 \\
\hline $\begin{array}{l}\text { CACNB } \\
2\end{array}$ & 34651 & Synaptic transmission, ion transport & 1.16 & 0.71 \\
\hline LASS6 & 35147 & $\begin{array}{l}\text { lipid biosynthetic process, regulation of transcription, } \\
\text { DNA-dependent }\end{array}$ & 1.15 & 0.75 \\
\hline LIG4 & 39274 & single strand break repair & 1.14 & 0.75 \\
\hline RNF8 & 39161 & protein ubiquitination & 1.14 & 0.00 \\
\hline
\end{tabular}




\begin{tabular}{|c|c|c|c|c|}
\hline Symbol & CloneID & Biological Process & $\begin{array}{c}\text { Fold } \\
\text { change }\end{array}$ & $\begin{array}{c}\text { q- } \\
\text { value } \\
(\%)\end{array}$ \\
\hline KCNIP4 & 21478 & ion transport & -1.13 & 0.00 \\
\hline RCC2 & 136887 & cell cycle, cell division, mitosis & -1.14 & 0.90 \\
\hline RBM4 & 141446 & $\begin{array}{c}\text { DNA recombination, DNA repair, DNA replication, } \\
\text { estrogen receptor signaling pathway, glucocorticoid } \\
\text { receptor signaling pathway, mRNA splicing }\end{array}$ & -1.19 & 0.00 \\
\hline $\begin{array}{c}\text { DENND } \\
\text { 1A }\end{array}$ & 21467 & synaptic vesicle endocytosis & -1.21 & 0.74 \\
\hline HSPB1 & 23827 & cell death, response to heat & -1.23 & 0.00 \\
\hline ARSJ & 32854 & Unknown & -1.24 & 0.00 \\
\hline $\begin{array}{c}\text { ATP6AP } \\
2\end{array}$ & 131821 & $\begin{array}{c}\text { angiotensin maturation, positive regulation of } \\
\text { transforming growth factor-beta1 production, regulation } \\
\text { of MAPKKK cascade }\end{array}$ & -1.29 & 0.00 \\
\hline UGDH & 139835 & UDP-glucose metabolism, electron transport & -1.41 & 0.00 \\
\hline DUSP22 & 182999 & $\begin{array}{c}\text { apoptosis, cell proliferation, development, inactivation of } \\
\text { MAPK, protein amino acid dephosphorylation }\end{array}$ & -1.55 & 0.00 \\
\hline PFKFB2 & 53158 & $\begin{array}{c}\text { glucose catabolic process, positive regulation of insulin } \\
\text { secretion, pyruvate metabolic process }\end{array}$ & -1.68 & 0.00 \\
\hline
\end{tabular}

Table 2. List of highly significant differentially expressed genes provided by SAM (FDR $\leq 0.68 \%$ ), comparing MT and WT TP53 GBM cell lines. Positive fold-change value means upregulation, while negative fold-change value means down-regulation in MT TP53 cells, compared to WT TP53 cells.

includes the spatial reorganization of DSB repair and signalling proteins into subnuclear structures surrounding DSB sites (Bartek and Lukas, 2007; Maser et al., 1997). In this context, RNF8 protein is an important component of the DNA damage response; it can be recruited to the DNA damage sites, thus triggering the formation of ubiquitin conjugates, promoting the recruitment of important proteins to DSB sites, thereby enhancing DNA-damage checkpoint events (G2/M) and guaranting cell survival (Kolas et al., 2007). There is also evidence that RNF8 participates in histone ubiquitylation and protects the genome integrity by licensing the DSB-flanking chromatin to concentrate repair factors near the DNA lesions (Mailand et al., 2007). LIG4 is also a key protein playing role in DSB repair by nonhomologous end joining (NHEJ) pathway (Helleday et al., 2007), while CAV1 presents a tumor suppressor function in non-neoplastic tissue, being down-regulated upon transformation, but re-expressed upon progression in metastatic and multidrug-resistant tumors (Burgermeister et al., 2008). CAV1 was also associated with multidrug resistance (Belanger et al., 2004; Belanger et al., 2003), and radioresistance (Barzan et al., 2010; Cordes et al., 2007; Li et al., 2005).

In MT TP53 cells, other stress response genes (RUVBL2 and ASNS) were up-regulated, while RBM4 was down-regulated. RUVBL2 participates in chromatin-remodelling (Lee et al., 2010), which could also let the lesion available to DNA repair genes. ASNS is a gene whose response elements function as an enhancer to mediate the transcriptional activation of the gene, either by the amino acid response (AAR) or the unfolded protein response (UPR pathway), triggered by amino acid limitation or endoplasmic reticulum stress (Siu et al., 
2002), respectively. These pathways initiate a wide array of adaptive mechanisms and ultimately, if necessary, programmed cell death (Harding et al., 2003; Zinszner et al., 1998); The role of $R B M 4$ in response to stress stimulus is the activation of internal ribosome entry site (IRES)-mediated translation, promoting the expression of stress-response genes; therefore, the down-regulation of RBM4 in MT TP53 cells might compromise the translational regulation of stress-associated mRNAs (Markus and Morris, 2009).

Several genes playing roles in cell adhesion were also differentially expressed in GBM cell lines, and this result is in accordance with the association of these genes in acquired chemoand radioresistance (Kraus et al., 2002). In the present work, three cadherins (CDH8, CDH13 and CD93), and one integrin ITGA5 were found up-regulated in MT TP53 cells, relatively to WT counterparts. Cadherins are integral membrane proteins that mediate calciumdependent cell-cell adhesion. They may play an important role in the development and maintenance of tissues, and possibly are involved in the invasion and metastasis of malignant tumors. While CDH8 participates in neural circuitry, CD93 is involved in phagocytosis (Bohlson et al., 2005), CDH13 play a role in apoptosis (Chan et al., 2008), and ITGA5 in cell spreading (Fang et al., 2010).

A comparative analysis of differentially expressed genes (provided by SAM) was performed with previously identified genes with TP53 binding sites; this comparison was possible by using ChIP-PET and ChIP-on-chip analyses (Smeenk et al., 2008; Wei et al., 2006). For the ChIP- PET gene lists, we observed only one common gene (LASS6), which was up-regulated in MT TP53 cells. LASS6 is a ceramide sintase, producing ceramides that have antiproliferative and pro-apoptotic effects (Ruvolo, 2003). This gene plays a role in apoptosis induction in colon cancer cells (Schiffmann et al., 2010), and enhanced tumor development and growth in vivo in human head and neck squamous cell carcinomas (HNSCCs) (Senkal et al., 2010).

In addition, the comparison involving our modulated gene list, comparing MT and WT TP53 GBM cells, using the ChIP-on-chip list, provided five common genes: ARSJ, RCC2, CDH8, CDH13 and HTRA1). While CDH8, CDH13 and HTRA1 were up-regulated, ARSJ and RCC2 were down-regulated in MT TP53 cells. CDH8 and CDH13 are cadherins and were already discussed as possible targets to chemo- and radioresistance (Kraus et al., 2002). HTRA1 is a tumor suppressor-like factor when overexpressed in cancer cell lines. (Baldi et al., 2002; Chien et al., 2004). This gene was also associated to cisplatin therapy responses in various cancer types (Catalano et al., 2011; Chien et al., 2006; Komatsu et al., 2006). These genes cannot be transactivated by TP53, according to the TP53 status in T98G and U251MG cells. However, the majority of the genome-wide TP53 target sites can also be bounded by overexpressed p63 and p73 in vivo, suggesting that they may possibly play an important role at TP53 binding sites (Smeenk et al., 2008). ARSJ and RCC2 genes were not described to be related with stress responses or cancer, and were up-regulated in WT TP53 GBM cells, compared to MT, and probably, they can be associated to transactivation properties of TP53.

Thus, in the present work, most genes involved in stress responses (RUVBL2, ASNS, RNF8, LIG4 and CAV1), cell adhesion (CDH8, CDH13, CD93 and ITGA5), and genes associated to p63 and p73 binding sites (LASS6 and HTRA1) were up-regulated in MT TP53 cells. At least some of them may have the potential to be directly involved in radioor chemoresistance. Therefore, the loss of TP53 function may compromise cellular responses to anticancer agents. 
It is already known that mechanisms underlying the cellular radiosensitivity seem to vary among different cell lineages, but at what extent the radiosensitivity depends on TP53 function is a matter of investigation since long time ago. Several authors demonstrated that the loss of TP53 function decreases the sensitivity of GBM cells to irradiation (Bartussek et al., 1999; Mcllwrath et al., 1994; Roy et al., 2006; Yount et al., 1996), and the same was observed for other tumor types (Fan et al., 1994; Komarova et al., 1997; Merritt et al., 1994). However, in primary gliomas, the TP53 mutation confers an improved prognosis in adult glioma patients due to a better response to radiation therapy (Tada et al., 1998). This is consistent with the results obtained in in vitro studies, in which glioma cells lacking WT TP53 function were more susceptible to radiation-induced apoptosis than their isogenic counterparts expressing WT TP53 (Hara et al., 2004).

It is important to emphasize that all these articles in the literature took into account the TP53 status, but not other mutations inherent to GBM. In the present work, we studied four GBM cell lines with different TP53 status; T98G and U251MG are mutated and U343MG-a and U87MG are wild-type for TP53 gene, but they are similar regarding the fact that they harbor mutations for CDKN2A and PTEN, according to Ishi et al. (1999). In experiments on cell survival performed by the clonogenic survival assay, the results provided by several authors indicated that MT TP53 cells were, in general, more radioresistant than WT TP53 cells (Bassi et al., 2008; Chautard et al., 2010; de la Pena et al., 2006; Lee et al., 2006; Roy et al., 2006).

As described above, several differentially expressed genes provided by the comparison between MT versus WT TP53 GBM cells are involved in the mechanism of resistance to ionizing radiation and/or multidrug resistance. In general, cytotoxicity of DNA damaging agents correlates with the induction of DSB, which can be produced directly or indirectly into the DNA molecule. Whereas ionizing radiation induces DSB directly, the drug TMZ generates DSB only after two or more cycles of DNA replication, as a secondary effect (Caporali et al., 2004). Therefore, TP53 mutation has the potential to change the sensitivity of GBM cells to anticancer agents currently used in therapy, and probably, the changes in the expression profiles exhibited by several genes acting down-stream in the signalling cascade of damage responses may compromise the outcome of drug- and radio- therapies. In order to understand these alterations in terms of transcript profiles, we are currently studying at what extent TP53 status influences gene expression profiles in irradiated GBM cells (manuscript in preparation); we found several differentially expressed genes in irradiated MT TP53 cells that are probably implicated in tumor resistance; among them, we can mention CLSTN2, ROBO2, and BMPR1B (with role in cell-cell adhesion), BTRC, CYP26B1, and ANLN (cell cycle regulators).

However, the data in the literature regarding the role of TP53 in mediating sensitivity to anticancer agents still present controversies. It has been reported that the absence of a functional TP53 increases TMZ sensitivity in glioma cell lines, an effect that is independent of MGMT status (Blough et al., 2011). Glioma cell lines that did not express a functional TP53 were significantly more sensitive to TMZ than cell lines that were functionally intact for TP53 expression (Blough et al., 2011). An example of this inconsistency comes from the results obtained with T98G cell line (MT TP53), in with the role of MGMT in mediating TMZ resistance was confirmed by the co-exposure to the MGMT inhibitor O6-BG, causing a reduction in the EC50, as evaluated by the clonogenic survival assay (Hermisson et al., 
2006). Nevertheless, the roles of TP53 in terms of its influence on drug sensitivity are difficult to elucidate, since the dependence on the cell type, and the kind of antitumor agent used(Fukushima et al., 2009). In addition, the genetic background is also critical, since GBM cells often harbor other mutations for cell cycle regulator genes, and other tumor suppressor genes, as already mentioned for the four GBM cell lines studied in the present work, which carry two other mutations (CDKN2A and PTEN).

The control of cell proliferation is very critical in the tumor development, and may also be influenced by the TP53 status (Facoetti et al., 2008). Several genes playing roles in the regulation of cell proliferation were found differentially expressed in MT TP53 cells, relatively to WT: IGFR1, CDH13, DUSP22, ADAMTS1, CAV1, and LIG4. These last two genes also play a role in stress responses, as mentioned before.

Tumor growth also depends on the rate of apoptosis (Amirlak and Couldwell, 2003), and apoptosis is directly involved in gliomagenesis and resistance towards classical genotoxic approaches in cancer therapy. It has been reported that GBM cells are virtually resistant to different apoptotic stimuli (Adamson et al., 2009; Eisele and Weller, 2011), but the mechanisms underlying these responses are still unclear, and may depend on several treatment conditions and type of genotoxic agent. In the present work, the list of differentially expressed genes also indicated several genes implicated in apoptosis. Those genes, such as IGF1R, CDH13, IFT57, CRH, HSPB1 and ASNS, were up-regulated in MT TP53 GBM cells, relatively to WT cells. IGF1R participates in cell proliferation and protection of cell death (Trojan et al., 2007), while CDH13, ITF57, CRH and ASNS participates in apoptosis induction (Andreeva and Kutuzov, 2010; Chan et al., 2008; Gdynia et al., 2008; Gervais et al., 2002; Minas et al., 2007; Siu et al., 2002). Considering that the ability of cells to undergo apoptosis is dependent of a complex signaling cascade involving pro- and antiapoptotic genes, among other gene classes, the up-regulation of several apoptosis related genes in MT TP53 cells might influence responses of GBM cells submitted to anticancer agents.

In this work, we showed some distinct transcript profiles for MT and WT TP53 GBM cells, pointing out several genes that might influence cell sensitivity to chemo- and/or radiotherapy.

\section{Conclusions}

The present data comparing transcript profiles displayed by GBM cell lines with different TP53 status showed that several biological processes were associated to the list of highly significant differentially expressed genes. Gene classes associated with those genes (stress response, DNA repair, proliferation, cell division, cell adhesion, apoptosis, etc) provided a picture on transcript profiles under normal conditions of cell proliferation in cultured GBM cell lines. However, these gene classes reflect wide amplitude of cellular processes that might be involved in cellular defense mechanisms under conditions of cell injury provoked by irradiation or drug treatment. These results support the hypothesis that MT TP53 cells might be more resistant than WT TP53 cells to some genotoxic stresses, such as ionizing radiation and TMZ. While this hypothesis still should be tested, altogether, the information obtained in this work provides a relevant basic contribution towards the understanding of GBM responses to therapies, and for designing novel therapeutic strategies for patients with GBM, based on their TP53 status, but also considering other gene mutations. 


\section{Supplementary data}

\begin{tabular}{|c|c|c|c|c|}
\hline Symbol & Gene Name & CloneID & $\begin{array}{l}\text { Fold } \\
\text { change }\end{array}$ & $\begin{array}{c}\text { q- } \\
\text { value } \\
(\%)\end{array}$ \\
\hline SPRY2 & Sprouty homolog 2 (Drosophila) & 40262 & 1.93 & 0.00 \\
\hline CAV1 & Caveolin 1 , caveolae protein, $22 \mathrm{kDa}$ & 24651 & 1.86 & 0.00 \\
\hline \multirow[t]{2}{*}{ MINA } & MYC induced nuclear antigen & 139217 & 1.79 & 0.00 \\
\hline & Clone 25220 mRNA sequence & 25220 & 1.63 & 0.00 \\
\hline CDH13 & Cadherin $13, \mathrm{H}$-cadherin (heart) & 31093 & 1.61 & 0.00 \\
\hline HTRA1 & HtrA serine peptidase 1 & 132044 & 1.55 & 0.00 \\
\hline ADAMTS1 & $\begin{array}{l}\text { ADAM metallopeptidase with } \\
\text { thrombospondin type } 1 \text { motif, } 1\end{array}$ & 34684 & 1.54 & 0.00 \\
\hline MPND & MPN domain containing & 24532 & 1.39 & 0.00 \\
\hline ARRB1 & Arrestin, beta 1 & 21814 & 1.38 & 0.00 \\
\hline ACSL4 & $\begin{array}{c}\text { Acyl-CoA synthetase long-chain family } \\
\text { member } 4\end{array}$ & 133988 & 1.36 & 0.00 \\
\hline ITGA5 & $\begin{array}{c}\text { Integrin, alpha } 5 \text { (fibronectin receptor, alpha } \\
\text { polypeptide) }\end{array}$ & 135671 & 1.35 & 0.75 \\
\hline $\mathrm{P} 4 \mathrm{HB}$ & Prolyl 4-hydroxylase, beta polypeptide & 132702 & 1.34 & 0.00 \\
\hline GPR68 & G protein-coupled receptor 68 & 22652 & 1.34 & 0.00 \\
\hline GPR44 & G protein-coupled receptor 44 & 25625 & 1.34 & 0.75 \\
\hline PDLIM1 & PDZ and LIM domain 1 & 135689 & 1.33 & 0.00 \\
\hline \multirow[t]{3}{*}{ RUVBL2 } & RuvB-like 2 (E. coli) & 22267 & 1.33 & 0.00 \\
\hline & In multiple ClusterIDs & 261714 & 1.32 & 0.00 \\
\hline & Unknown & 134004 & 1.32 & 0.00 \\
\hline ZXDB & Zinc finger, $X$-linked, duplicated B & 38972 & 1.31 & 0.90 \\
\hline MKLN1 & $\begin{array}{c}\text { Muskelin 1, intracellular mediator } \\
\text { containing kelch motifs }\end{array}$ & 33715 & 1.31 & 0.00 \\
\hline LARP4 & $\begin{array}{l}\text { La ribonucleoprotein domain family, } \\
\text { member } 4\end{array}$ & 41347 & 1.31 & 0.71 \\
\hline KSR1 & Kinase suppressor of ras 1 & 220655 & 1.31 & 0.75 \\
\hline JAKMIP1 & $\begin{array}{l}\text { Janus kinase and microtubule interacting } \\
\text { protein } 1\end{array}$ & 32109 & 1.30 & 0.00 \\
\hline
\end{tabular}




\begin{tabular}{|c|c|c|c|c|}
\hline GNG13 & $\begin{array}{l}\text { Guanine nucleotide binding protein ( } \mathrm{G} \\
\text { protein), gamma } 13\end{array}$ & 178213 & 1.30 & 0.75 \\
\hline ANKRD42 & $\begin{array}{c}\text { MRNA; cDNA DKFZp761C0524 (from clone } \\
\text { DKFZp761C0524) }\end{array}$ & 30094 & 1.30 & 0.00 \\
\hline $\mathrm{CDH} 8$ & cadherin 8 , type 2 & 38939 & 1.30 & 0.00 \\
\hline NRGN & $\begin{array}{c}\text { Neurogranin (protein kinase C substrate, } \\
\text { RC3) }\end{array}$ & 178825 & 1.30 & 0.75 \\
\hline USP53 & Ubiquitin specific peptidase 53 & 142468 & 1.30 & 0.69 \\
\hline PIP5K2C & $\begin{array}{l}\text { Phosphatidylinositol-5-phosphate 4-kinase, } \\
\text { type II, gamma }\end{array}$ & 133173 & 1.30 & 0.75 \\
\hline WDR34 & WD repeat domain 34 & 133474 & 1.29 & 0.00 \\
\hline TCBA1 & $\mathrm{Na}+/ \mathrm{K}+$ transporting ATPase interacting 2 & 41427 & 1.29 & 0.00 \\
\hline MGC14376 & Chromosome 17 open reading frame 91 & 24659 & 1.28 & 0.00 \\
\hline DNAJA1 & $\begin{array}{c}\text { DnaJ (Hsp40) homolog, subfamily A, } \\
\text { member } 1\end{array}$ & 24473 & 1.28 & 0.75 \\
\hline KLF12 & Kruppel-like factor 12 & 34367 & 1.28 & 0.00 \\
\hline UNC13C & unc-13 homolog C (C. elegans) & 22137 & 1.27 & 0.00 \\
\hline RHOQ & Ras homolog gene family, member $\mathrm{Q}$ & 131061 & 1.26 & 0.00 \\
\hline FBXL3 & F-box and leucine-rich repeat protein 3 & 25778 & 1.26 & 0.00 \\
\hline \multirow[t]{2}{*}{$\begin{array}{c}\text { RP11- } \\
484 I 6.3\end{array}$} & Chromosome 13 open reading frame 27 & 24463 & 1.25 & 0.00 \\
\hline & Unknown & 132487 & 1.25 & 0.75 \\
\hline $\mathrm{CRH}$ & Corticotropin releasing hormone & 34671 & 1.24 & 0.00 \\
\hline IGF1R & insulin-like growth factor 1 receptor & 21519 & 1.24 & 0.00 \\
\hline ASNS & $\begin{array}{c}\text { Asparagine synthetase (glutamine- } \\
\text { hydrolyzing) }\end{array}$ & 27208 & 1.23 & 0.90 \\
\hline CSGlcA-T & Chondroitin polymerizing factor 2 & 39955 & 1.23 & 0.75 \\
\hline NBPF12 & Neuroblastoma breakpoint family, member 1 & 24976 & 1.23 & 0.90 \\
\hline BAMBI & $\begin{array}{l}\text { BMP and activin membrane-bound inhibitor } \\
\text { homolog (Xenopus laevis) }\end{array}$ & 41406 & 1.22 & 0.00 \\
\hline \multirow[t]{2}{*}{ PDXK } & Pyridoxal (pyridoxine, vitamin B6) kinase & 25360 & 1.22 & 0.00 \\
\hline & Transcribed locus & 136399 & 1.21 & 0.75 \\
\hline TNRC15 & Transcribed locus & 37482 & 1.21 & 0.75 \\
\hline
\end{tabular}




\begin{tabular}{|c|c|c|c|c|}
\hline & Calneuron 1 & 39092 & 1.20 & 0.75 \\
\hline \multirow[t]{2}{*}{ 3-Mar } & Membrane-associated ring finger $(\mathrm{C} 3 \mathrm{HC} 4) 3$ & 24707 & 1.20 & 0.00 \\
\hline & Unknown & 39306 & 1.19 & 0.69 \\
\hline CD93 & CD93 molecule & 35503 & 1.19 & 0.00 \\
\hline \multirow[t]{3}{*}{ C20orf39 } & Transmembrane protein 90B & 35704 & 1.19 & 0.00 \\
\hline & In multiple ClusterIDs & 41186 & 1.19 & 0.71 \\
\hline & CXXC finger protein 5 & 136782 & 1.18 & 0.00 \\
\hline PPCDC & Phosphopantothenoylcysteine decarboxylase & 135984 & 1.18 & 0.00 \\
\hline \multirow[t]{2}{*}{ COPB2 } & Clone 24627 mRNA sequence & 24627 & 1.18 & 0.00 \\
\hline & CDNA FLJ34038 fis, clone FCBBF2005645 & 38618 & 1.18 & 0.00 \\
\hline FLJ41130 & hypothetical LOC401113 & 40009 & 1.18 & 0.00 \\
\hline \multirow[t]{2}{*}{ CPD } & Carboxypeptidase D & 40521 & 1.18 & 0.75 \\
\hline & Unknown & 34967 & 1.16 & 0.90 \\
\hline CACNB2 & $\begin{array}{c}\text { calcium channel, voltage-dependent, beta } 2 \\
\text { subunit }\end{array}$ & 34651 & 1.16 & 0.71 \\
\hline \multirow[t]{2}{*}{ CUTL2 } & Cut-like homeobox 2 & 41354 & 1.16 & 0.90 \\
\hline & Unknown & 34966 & 1.15 & 0.00 \\
\hline LASS6 & LAG1 homolog, ceramide synthase 6 & 35147 & 1.15 & 0.75 \\
\hline LIG4 & Ligase IV, DNA, ATP-dependent & 39274 & 1.14 & 0.75 \\
\hline RNF8 & Ring finger protein 8 & 39161 & 1.14 & 0.00 \\
\hline IFT57 & $\begin{array}{l}\text { Intraflagellar transport } 57 \text { homolog } \\
\text { (Chlamydomonas) }\end{array}$ & 34942 & 1.12 & 0.00 \\
\hline PIGO & $\begin{array}{l}\text { Phosphatidylinositol glycan anchor } \\
\text { biosynthesis, class O }\end{array}$ & 21678 & -1.12 & 0.71 \\
\hline KCNIP4 & Kv channel interacting protein 4 & 21478 & -1.13 & 0.00 \\
\hline RCC2 & Regulator of chromosome condensation 2 & 136887 & -1.16 & 0.90 \\
\hline PKIB & $\begin{array}{c}\text { Protein kinase (cAMP-dependent, catalytic) } \\
\text { inhibitor beta }\end{array}$ & 152289 & -1.17 & 0.00 \\
\hline DDX18 & $\begin{array}{l}\text { DEAD (Asp-Glu-Ala-Asp) box polypeptide } \\
\qquad 18\end{array}$ & 149416 & -1.17 & 0.00 \\
\hline SIN3A & $\begin{array}{c}\text { SIN3 homolog A, transcription regulator } \\
\text { (yeast) }\end{array}$ & 26455 & -1.18 & 0.00 \\
\hline
\end{tabular}




\begin{tabular}{|c|c|c|c|c|}
\hline RBM4 & RNA binding motif protein 4 & 141446 & -1.19 & 0.00 \\
\hline NKIRAS2 & NFKB inhibitor interacting Ras-like 2 & 137971 & -1.20 & 0.00 \\
\hline DENND1A & DENN/MADD domain containing 1A & 21467 & -1.21 & 0.74 \\
\hline TMLHE & Trimethyllysine hydroxylase, epsilon & 21457 & -1.22 & 0.00 \\
\hline HSPB1 & heat shock $27 \mathrm{kDa}$ protein 1 & 23827 & -1.23 & 0.00 \\
\hline ZNF630 & Zinc finger protein 630 & 141069 & -1.24 & 0.00 \\
\hline ARSJ & Arylsulfatase family, member J & 32854 & -1.24 & 0.00 \\
\hline NUP160 & Nucleoporin $160 \mathrm{kDa}$ & 33299 & -1.25 & 0.00 \\
\hline SCP2 & Sterol carrier protein 2 & 137004 & -1.26 & 0.68 \\
\hline NRN1 & Neuritin 1 & 140197 & -1.28 & 0.00 \\
\hline ATP6AP2 & $\begin{array}{l}\text { ATPase, } \mathrm{H}+\text { transporting, lysosomal } \\
\text { accessory protein } 2\end{array}$ & 131821 & -1.29 & 0.00 \\
\hline \multirow[t]{2}{*}{ PRPS2 } & Phosphoribosyl pyrophosphate synthetase 2 & 146194 & -1.32 & 0.00 \\
\hline & $\begin{array}{l}\text { Transcribed locus, weakly similar to } \\
\text { XP_933787.2 PREDICTED: hypothetical } \\
\text { protein [Homo sapiens] }\end{array}$ & 53331 & -1.34 & 0.00 \\
\hline PRSS23 & Protease, serine, 23 & 143887 & -1.35 & 0.00 \\
\hline CMPK & $\begin{array}{c}\text { Cytidine monophosphate (UMP-CMP) } \\
\text { kinase } 1 \text {, cytosolic }\end{array}$ & 140570 & -1.36 & 0.00 \\
\hline UGDH & UDP-glucose 6-dehydrogenase & 139835 & -1.41 & 0.00 \\
\hline \multirow[t]{2}{*}{ VSNL1 } & Visinin-like 1 & 26570 & -1.42 & 0.00 \\
\hline & Transcribed locus & 139645 & -1.44 & 0.00 \\
\hline SSFA2 & Sperm specific antigen 2 & 140589 & -1.45 & 0.00 \\
\hline \multirow[t]{2}{*}{ ABCA7 } & $\begin{array}{c}\text { ATP-binding cassette, sub-family A (ABC1), } \\
\text { member } 7\end{array}$ & 182933 & -1.45 & 0.00 \\
\hline & Unknown & 181796 & -1.54 & 0.00 \\
\hline DUSP22 & Dual specificity phosphatase 22 & 182999 & -1.55 & 0.00 \\
\hline PFKFB2 & $\begin{array}{l}\text { 6-phosphofructo-2-kinase/fructose-2,6- } \\
\text { biphosphatase } 2\end{array}$ & 53158 & -1.68 & 0.00 \\
\hline
\end{tabular}

Table 1. List of significantly modulated genes provided by the statistical analysis by SAM (FDR $\leq 0.68 \%$ ), comparing MT versus WT TP53 GBM cell lines. 


\section{Acknowledgment}

This study was supported by FAPESP (Fundação de Amparo à pesquisa de São Paulo), proc. no: 04/15611-6, 06/01947-8 and 01953-8/06; CNPq (Conselho Nacional de Desenvolvimento Científico e Tecnológico); CAPES (Coordenação de Aperfeiçoamento de Pessoal de nível Superior); and FAEPA - HC FMRP/USP (Fundação de Apoio ao Ensino, Pesquisa e Assistência).

\section{References}

Adamson, C., Kanu, O. O., Mehta, A. I., Di, C., Lin, N., Mattox, A. K., and Bigner, D. D. (2009). Glioblastoma multiforme: a review of where we have been and where we are going. Expert Opin Investig Drugs 18, 1061-1083.

Amirlak, B., and Couldwell, W. T. (2003). Apoptosis in glioma cells: review and analysis of techniques used for study with focus on the laser scanning cytometer. J Neurooncol 63, 129-145.

Andreeva, A. V., and Kutuzov, M. A. (2010). Cadherin 13 in cancer. Genes Chromosomes Cancer 49, 775-790.

Avgeropoulos, N. G., and Batchelor, T. T. (1999). New treatment strategies for malignant gliomas. Oncologist 4, 209-224.

Baldi, A., De Luca, A., Morini, M., Battista, T., Felsani, A., Baldi, F., Catricala, C., Amantea, A., Noonan, D. M., Albini, A., et al. (2002). The HtrA1 serine protease is downregulated during human melanoma progression and represses growth of metastatic melanoma cells. Oncogene 21, 6684-6688.

Bartek, J., and Lukas, J. (2007). DNA damage checkpoints: from initiation to recovery or adaptation. Curr Opin Cell Biol 19, 238-245.

Bartussek, C., Naumann, U., and Weller, M. (1999). Accumulation of mutant p53(V143A) modulates the growth, clonogenicity, and radiochemosensitivity of malignant glioma cells independent of endogenous p53 status. Exp Cell Res 253, 432-439.

Barzan, D., Maier, P., Zeller, W. J., Wenz, F., and Herskind, C. (2010). Overexpression of caveolin-1 in lymphoblastoid TK6 cells enhances proliferation after irradiation with clinically relevant doses. Strahlenther Onkol 186, 99-106.

Bassi, C., Mello, S., Cardoso, R., Godoy, P., Fachin, A., Junta, C., Sandrin-Garcia, P., Carlotti, C., Falcao, R., Donadi, E., et al. (2008). Transcriptional changes in U343 MG-a glioblastoma cell line exposed to ionizing radiation. Hum Exp Toxicol 27, 919-929.

Batista, L. F., Roos, W. P., Christmann, M., Menck, C. F., and Kaina, B. (2007). Differential sensitivity of malignant glioma cells to methylating and chloroethylating anticancer drugs: p53 determines the switch by regulating xpc, ddb2, and DNA double-strand breaks. Cancer Res 67, 11886-11895.

Batista, L. F., Roos, W. P., Kaina, B., and Menck, C. F. (2009). p53 mutant human glioma cells are sensitive to UV-C-induced apoptosis due to impaired cyclobutane pyrimidine dimer removal. Mol Cancer Res 7, 237-246.

Belanger, M. M., Gaudreau, M., Roussel, E., and Couet, J. (2004). Role of caveolin-1 in etoposide resistance development in A549 lung cancer cells. Cancer Biol Ther 3, 954-959. 
Belanger, M. M., Roussel, E., and Couet, J. (2003). Up-regulation of caveolin expression by cytotoxic agents in drug-sensitive cancer cells. Anticancer Drugs 14, 281-287.

Blough, M. D., Beauchamp, D. C., Westgate, M. R., Kelly, J. J., and Cairncross, J. G. (2011). Effect of aberrant p53 function on temozolomide sensitivity of glioma cell lines and brain tumor initiating cells from glioblastoma. J Neurooncol 102, 1-7.

Bohlson, S. S., Zhang, M., Ortiz, C. E., and Tenner, A. J. (2005). CD93 interacts with the PDZ domain-containing adaptor protein GIPC: implications in the modulation of phagocytosis. J Leukoc Biol 77, 80-89.

Burgermeister, E., Liscovitch, M., Rocken, C., Schmid, R. M., and Ebert, M. P. (2008). Caveats of caveolin-1 in cancer progression. Cancer Lett 268, 187-201.

Caporali, S., Falcinelli, S., Starace, G., Russo, M. T., Bonmassar, E., Jiricny, J., and D'Atri, S. (2004). DNA damage induced by temozolomide signals to both ATM and ATR: role of the mismatch repair system. Mol Pharmacol 66, 478-491.

Castells, X., Acebes, J. J., Boluda, S., Moreno-Torres, A., Pujol, J., Julia-Sape, M., Candiota, A. P., Arino, J., Barcelo, A., and Arus, C. (2010). Development of a predictor for human brain tumors based on gene expression values obtained from two types of microarray technologies. OMICS 14, 157-164.

Castells, X., Garcia-Gomez, J. M., Navarro, A., Acebes, J. J., Godino, O., Boluda, S., Barcelo, A., Robles, M., Arino, J., and Arus, C. (2009). Automated brain tumor biopsy prediction using single-labeling cDNA microarrays-based gene expression profiling. Diagn Mol Pathol 18, 206-218.

Catalano, V., Mellone, P., d'Avino, A., Shridhar, V., Staccioli, M. P., Graziano, F., Giordani, P., Rossi, D., Baldelli, A. M., Alessandroni, P., et al. (2011). HtrA1, a potential predictor of response to cisplatin-based combination chemotherapy in gastric cancer. Histopathology.

Chan, D. W., Lee, J. M., Chan, P. C., and Ng, I. O. (2008). Genetic and epigenetic inactivation of T-cadherin in human hepatocellular carcinoma cells. Int J Cancer 123, 1043-1052.

Chautard, E., Loubeau, G., Tchirkov, A., Chassagne, J., Vermot-Desroches, C., Morel, L., and Verrelle, P. (2010). Akt signaling pathway: a target for radiosensitizing human malignant glioma. Neuro Oncol 12, 434-443.

Chien, J., Aletti, G., Baldi, A., Catalano, V., Muretto, P., Keeney, G. L., Kalli, K. R., Staub, J., Ehrmann, M., Cliby, W. A., et al. (2006). Serine protease HtrA1 modulates chemotherapy-induced cytotoxicity. J Clin Invest 116, 1994-2004.

Chien, J., Staub, J., Hu, S. I., Erickson-Johnson, M. R., Couch, F. J., Smith, D. I., Crowl, R. M., Kaufmann, S. H., and Shridhar, V. (2004). A candidate tumor suppressor HtrA1 is downregulated in ovarian cancer. Oncogene 23, 1636-1644.

Cordes, N., Frick, S., Brunner, T. B., Pilarsky, C., Grutzmann, R., Sipos, B., Kloppel, G., McKenna, W. G., and Bernhard, E. J. (2007). Human pancreatic tumor cells are sensitized to ionizing radiation by knockdown of caveolin-1. Oncogene 26, 68516862.

de la Pena, L., Burgan, W. E., Carter, D. J., Hollingshead, M. G., Satyamitra, M., Camphausen, K., and Tofilon, P. J. (2006). Inhibition of Akt by the alkylphospholipid perifosine does not enhance the radiosensitivity of human glioma cells. Mol Cancer Ther 5, 1504-1510. 
Dreyfuss, J. M., Johnson, M. D., and Park, P. J. (2009). Meta-analysis of glioblastoma multiforme versus anaplastic astrocytoma identifies robust gene markers. Mol Cancer 8, 71 .

Eisele, G., and Weller, M. (2011). Targeting apoptosis pathways in glioblastoma. Cancer Lett. Eisen, M. B., Spellman, P. T., Brown, P. O., and Botstein, D. (1998). Cluster analysis and display of genome wide expression patterns. Proc Natl Acad Sci U S A 95, 1486314868.

el-Deiry, W. S. (1998). Regulation of p53 downstream genes. Semin Cancer Biol 8, 345-357.

Facoetti, A., Ranza, E., and Nano, R. (2008). Proliferation and programmed cell death: role of p53 protein in high and low grade astrocytoma. Anticancer Res 28, 15-19.

Fan, S., el-Deiry, W. S., Bae, I., Freeman, J., Jondle, D., Bhatia, K., Fornace, A. J., Jr., Magrath, I., Kohn, K. W., and O'Connor, P. M. (1994). p53 gene mutations are associated with decreased sensitivity of human lymphoma cells to DNA damaging agents. Cancer Res 54, 5824-5830.

Fang, Z., Yao, W., Xiong, Y., Zhang, J., Liu, L., Li, J., Zhang, C., and Wan, J. (2010). Functional elucidation and methylation-mediated downregulation of ITGA5 gene in breast cancer cell line MDA-MB-468. J Cell Biochem 110, 1130-1141.

Fukushima, T., Takeshima, H., and Kataoka, H. (2009). Anti-glioma therapy with temozolomide and status of the DNA-repair gene MGMT. Anticancer Res 29, 48454854.

Gdynia, G., Lehmann-Koch, J., Sieber, S., Tagscherer, K. E., Fassl, A., Zentgraf, H., Matsuzawa, S., Reed, J. C., and Roth, W. (2008). BLOC1S2 interacts with the HIPPI protein and sensitizes NCH89 glioblastoma cells to apoptosis. Apoptosis 13, 437447.

Gervais, F. G., Singaraja, R., Xanthoudakis, S., Gutekunst, C. A., Leavitt, B. R., Metzler, M., Hackam, A. S., Tam, J., Vaillancourt, J. P., Houtzager, V., et al. (2002). Recruitment and activation of caspase- 8 by the Huntingtin-interacting protein Hip-1 and a novel partner Hippi. Nat Cell Biol 4, 95-105.

Hara, S., Nakashima, S., Kiyono, T., Sawada, M., Yoshimura, S., Iwama, T., Banno, Y., Shinoda, J., and Sakai, N. (2004). p53-Independent ceramide formation in human glioma cells during gamma-radiation-induced apoptosis. Cell Death Differ 11, 853861.

Harding, H. P., Zhang, Y., Zeng, H., Novoa, I., Lu, P. D., Calfon, M., Sadri, N., Yun, C., Popko, B., Paules, R., et al. (2003). An integrated stress response regulates amino acid metabolism and resistance to oxidative stress. Mol Cell 11, 619-633.

Hegi, M. E., Diserens, A. C., Gorlia, T., Hamou, M. F., de Tribolet, N., Weller, M., Kros, J. M., Hainfellner, J. A., Mason, W., Mariani, L., et al. (2005). MGMT gene silencing and benefit from temozolomide in glioblastoma. N Engl J Med 352, 997-1003.

Helleday, T., Lo, J., van Gent, D. C., and Engelward, B. P. (2007). DNA double-strand break repair: from mechanistic understanding to cancer treatment. DNA Repair (Amst) 6, 923-935.

Hermisson, M., Klumpp, A., Wick, W., Wischhusen, J., Nagel, G., Roos, W., Kaina, B., and Weller, M. (2006). O6-methylguanine DNA methyltransferase and p53 status 
predict temozolomide sensitivity in human malignant glioma cells. J Neurochem 96, 766-776.

Hoh, J., Jin, S., Parrado, T., Edington, J., Levine, A. J., and Ott, J. (2002). The p53MH algorithm and its application in detecting p53-responsive genes. Proc Natl Acad Sci U S A 99, 8467-8472.

Horn, H. F., and Vousden, K. H. (2007). Coping with stress: multiple ways to activate p53. Oncogene 26, 1306-1316.

Kolas, N. K., Chapman, J. R., Nakada, S., Ylanko, J., Chahwan, R., Sweeney, F. D., Panier, S., Mendez, M., Wildenhain, J., Thomson, T. M., et al. (2007). Orchestration of the DNA-damage response by the RNF8 ubiquitin ligase. Science 318, 1637-1640.

Komarova, E. A., Chernov, M. V., Franks, R., Wang, K., Armin, G., Zelnick, C. R., Chin, D. M., Bacus, S. S., Stark, G. R., and Gudkov, A. V. (1997). Transgenic mice with p53responsive lacZ: p53 activity varies dramatically during normal development and determines radiation and drug sensitivity in vivo. Embo J 16, 1391-1400.

Komatsu, M., Hiyama, K., Tanimoto, K., Yunokawa, M., Otani, K., Ohtaki, M., Hiyama, E., Kigawa, J., Ohwada, M., Suzuki, M., et al. (2006). Prediction of individual response to platinum/paclitaxel combination using novel marker genes in ovarian cancers. Mol Cancer Ther 5, 767-775.

Kraus, A. C., Ferber, I., Bachmann, S. O., Specht, H., Wimmel, A., Gross, M. W., Schlegel, J., Suske, G., and Schuermann, M. (2002). In vitro chemo- and radio-resistance in small cell lung cancer correlates with cell adhesion and constitutive activation of AKT and MAP kinase pathways. Oncogene 21, 8683-8695.

Laptenko, O., and Prives, C. (2006). Transcriptional regulation by p53: one protein, many possibilities. Cell Death Differ 13, 951-961.

Lee, J. S., Kim, Y., Kim, I. S., Kim, B., Choi, H. J., Lee, J. M., Shin, H. J., Kim, J. H., Kim, J. Y., Seo, S. B., et al. (2010). Negative regulation of hypoxic responses via induced Reptin methylation. Mol Cell 39, 71-85.

Lee, Y. J., Chung, D. Y., Lee, S. J., Ja Jhon, G., and Lee, Y. S. (2006). Enhanced radiosensitization of p53 mutant cells by oleamide. Int J Radiat Oncol Biol Phys 64, 1466-1474.

Li, J., Hassan, G. S., Williams, T. M., Minetti, C., Pestell, R. G., Tanowitz, H. B., Frank, P. G., Sotgia, F., and Lisanti, M. P. (2005). Loss of caveolin-1 causes the hyperproliferation of intestinal crypt stem cells, with increased sensitivity to whole body gamma-radiation. Cell Cycle 4, 1817-1825.

Mailand, N., Bekker-Jensen, S., Faustrup, H., Melander, F., Bartek, J., Lukas, C., and Lukas, J. (2007). RNF8 ubiquitylates histones at DNA double-strand breaks and promotes assembly of repair proteins. Cell 131, 887-900.

Markus, M. A., and Morris, B. J. (2009). RBM4: a multifunctional RNA-binding protein. Int J Biochem Cell Biol 41, 740-743.

Marucci, G., Morandi, L., Magrini, E., Farnedi, A., Franceschi, E., Miglio, R., Calo, D., Pession, A., Foschini, M. P., and Eusebi, V. (2008). Gene expression profiling in glioblastoma and immunohistochemical evaluation of IGFBP-2 and CDC20. Virchows Arch 453, 599-609. 
Maser, R. S., Monsen, K. J., Nelms, B. E., and Petrini, J. H. (1997). hMre11 and hRad50 nuclear foci are induced during the normal cellular response to DNA double strand breaks. Mol Cell Biol 17, 6087-6096.

Mcllwrath, A. J., Vasey, P. A., Ross, G. M., and Brown, R. (1994). Cell cycle arrests and radiosensitivity of human tumor cell lines: dependence on wild-type p53 for radiosensitivity. Cancer Res 54, 3718-3722.

Mehrian Shai, R., Reichardt, J. K., Ya-Hsuan, H., Kremen, T. J., Liau, L. M., Cloughesy, T. F., Mischel, P. S., and Nelson, S. F. (2005). Robustness of gene expression profiling in glioma specimen samplings and derived cell lines. Brain Res Mol Brain Res 136, 99103.

Merritt, A. J., Potten, C. S., Kemp, C. J., Hickman, J. A., Balmain, A., Lane, D. P., and Hall, P. A. (1994). The role of p53 in spontaneous and radiation-induced apoptosis in the gastrointestinal tract of normal and p53-deficient mice. Cancer Res 54, 614-617.

Minas, V., Rolaki, A., Kalantaridou, S. N., Sidiropoulos, J., Mitrou, S., Petsas, G., Jeschke, U., Paraskevaidis, E. A., Fountzilas, G., Chrousos, G. P., et al. (2007). Intratumoral CRH modulates immuno-escape of ovarian cancer cells through FasL regulation. Br J Cancer 97, 637-645.

Ohgaki, H., and Kleihues, P. (2005). Population-based studies on incidence, survival rates, and genetic alterations in astrocytic and oligodendroglial gliomas. J Neuropathol Exp Neurol 64, 479-489.

Prise, K. M., Schettino, G., Folkard, M., and Held, K. D. (2005). New insights on cell death from radiation exposure. Lancet Oncol 6, 520-528.

Reddy, S. P., Britto, R., Vinnakota, K., Aparna, H., Sreepathi, H. K., Thota, B., Kumari, A., Shilpa, B. M., Vrinda, M., Umesh, S., et al. (2008). Novel glioblastoma markers with diagnostic and prognostic value identified through transcriptome analysis. Clin Cancer Res 14, 2978-2987.

Roos, W. P., Batista, L. F., Naumann, S. C., Wick, W., Weller, M., Menck, C. F., and Kaina, B. (2007). Apoptosis in malignant glioma cells triggered by the temozolomide-induced DNA lesion O6-methylguanine. Oncogene 26, 186-197.

Roy, K., Wang, L., Makrigiorgos, G. M., and Price, B. D. (2006). Methylation of the ATM promoter in glioma cells alters ionizing radiation sensitivity. Biochem Biophys Res Commun 344, 821-826.

Ruvolo, P. P. (2003). Intracellular signal transduction pathways activated by ceramide and its metabolites. Pharmacol Res 47, 383-392.

Sallinen, S. L., Sallinen, P. K., Haapasalo, H. K., Helin, H. J., Helen, P. T., Schraml, P., Kallioniemi, O. P., and Kononen, J. (2000). Identification of differentially expressed genes in human gliomas by DNA microarray and tissue chip techniques. Cancer Res 60, 6617-6622.

Sbisa, E., Catalano, D., Grillo, G., Licciulli, F., Turi, A., Liuni, S., Pesole, G., De Grassi, A., Caratozzolo, M. F., D'Erchia, A. M., et al. (2007). p53FamTaG: a database resource of human p53, p63 and p73 direct target genes combining in silico prediction and microarray data. BMC Bioinformatics 8 Suppl 1, S20.

Schiffmann, S., Ziebell, S., Sandner, J., Birod, K., Deckmann, K., Hartmann, D., Rode, S., Schmidt, H., Angioni, C., Geisslinger, G., and Grosch, S. (2010). Activation of 
ceramide synthase 6 by celecoxib leads to a selective induction of C16:0-ceramide. Biochem Pharmacol 80, 1632-1640.

Senkal, C. E., Ponnusamy, S., Bielawski, J., Hannun, Y. A., and Ogretmen, B. (2010). Antiapoptotic roles of ceramide-synthase-6-generated C16-ceramide via selective regulation of the ATF6/CHOP arm of ER-stress-response pathways. FASEB J 24, 296-308.

Siu, F., Bain, P. J., LeBlanc-Chaffin, R., Chen, H., and Kilberg, M. S. (2002). ATF4 is a mediator of the nutrient-sensing response pathway that activates the human asparagine synthetase gene. J Biol Chem 277, 24120-24127.

Slichenmyer, W. J., Nelson, W. G., Slebos, R. J., and Kastan, M. B. (1993). Loss of a p53associated G1 checkpoint does not decrease cell survival following DNA damage. Cancer Res 53, 4164-4168.

Smeenk, L., van Heeringen, S. J., Koeppel, M., van Driel, M. A., Bartels, S. J., Akkers, R. C., Denissov, S., Stunnenberg, H. G., and Lohrum, M. (2008). Characterization of genome-wide p53-binding sites upon stress response. Nucleic Acids Res 36, 36393654 .

Smith, M. L., Chen, I. T., Zhan, Q., O'Connor, P. M., and Fornace, A. J., Jr. (1995). Involvement of the p53 tumor suppressor in repair of u.v.-type DNA damage. Oncogene 10, 1053-1059.

Stupp, R., Hegi, M. E., Gilbert, M. R., and Chakravarti, A. (2007). Chemoradiotherapy in malignant glioma: standard of care and future directions. J Clin Oncol 25, 41274136.

Stupp, R., Mason, W. P., van den Bent, M. J., Weller, M., Fisher, B., Taphoorn, M. J., Belanger, K., Brandes, A. A., Marosi, C., Bogdahn, U., et al. (2005). Radiotherapy plus concomitant and adjuvant temozolomide for glioblastoma. N Engl J Med 352, 987-996.

Tada, M., Matsumoto, R., Iggo, R. D., Onimaru, R., Shirato, H., Sawamura, Y., and Shinohe, Y. (1998). Selective sensitivity to radiation of cerebral glioblastomas harboring p53 mutations. Cancer Res 58, 1793-1797.

Trojan, J., Cloix, J. F., Ardourel, M. Y., Chatel, M., and Anthony, D. D. (2007). Insulin-like growth factor type I biology and targeting in malignant gliomas. Neuroscience 145, 795-811.

Veprintsev, D. B., and Fersht, A. R. (2008). Algorithm for prediction of tumour suppressor p53 affinity for binding sites in DNA. Nucleic Acids Res 36, 1589-1598.

Vogelstein, B., Lane, D., and Levine, A. J. (2000). Surfing the p53 network. Nature 408, 307310.

Wei, C. L., Wu, Q., Vega, V. B., Chiu, K. P., Ng, P., Zhang, T., Shahab, A., Yong, H. C., Fu, Y., Weng, Z., et al. (2006). A global map of p53 transcription-factor binding sites in the human genome. Cell 124, 207-219.

Yount, G. L., Haas-Kogan, D. A., Vidair, C. A., Haas, M., Dewey, W. C., and Israel, M. A. (1996). Cell cycle synchrony unmasks the influence of p53 function on radiosensitivity of human glioblastoma cells. Cancer Res 56, 500-506. 
Zhang, J., Stevens, M. F., Laughton, C. A., Madhusudan, S., and Bradshaw, T. D. (2010). Acquired resistance to temozolomide in glioma cell lines: molecular mechanisms and potential translational applications. Oncology 78, 103-114.

Zinszner, H., Kuroda, M., Wang, X., Batchvarova, N., Lightfoot, R. T., Remotti, H., Stevens, J. L., and Ron, D. (1998). CHOP is implicated in programmed cell death in response to impaired function of the endoplasmic reticulum. Genes Dev 12, 982-995. 


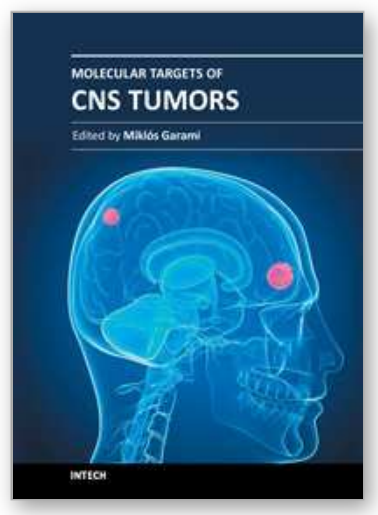

\author{
Molecular Targets of CNS Tumors \\ Edited by Dr. Miklos Garami
}

ISBN 978-953-307-736-9

Hard cover, 674 pages

Publisher InTech

Published online 22, September, 2011

Published in print edition September, 2011

Molecular Targets of CNS Tumors is a selected review of Central Nervous System (CNS) tumors with particular emphasis on signaling pathway of the most common CNS tumor types. To develop drugs which specifically attack the cancer cells requires an understanding of the distinct characteristics of those cells. Additional detailed information is provided on selected signal pathways in CNS tumors.

\title{
How to reference
}

In order to correctly reference this scholarly work, feel free to copy and paste the following:

Paulo R. D. V. Godoy, Stephano S. Mello, Daniele A. Magalhães, Flavia S. Donaires, Ana P. Lima-Montaldi, Patricia Nicolucci, Eduardo A. Donadi, Geraldo A. S. Passos and Elza T. Sakamoto-Hojo (2011). Portrait of Transcriptional Expression Profiles Displayed by Different Glioblastoma Cell Lines, Molecular Targets of CNS Tumors, Dr. Miklos Garami (Ed.), ISBN: 978-953-307-736-9, InTech, Available from:

http://www.intechopen.com/books/molecular-targets-of-cns-tumors/portrait-of-transcriptional-expressionprofiles-displayed-by-different-glioblastoma-cell-lines

\section{INTECH}

open science | open minds

\section{InTech Europe}

University Campus STeP Ri

Slavka Krautzeka 83/A

51000 Rijeka, Croatia

Phone: +385 (51) 770447

Fax: +385 (51) 686166

www.intechopen.com

\section{InTech China}

Unit 405, Office Block, Hotel Equatorial Shanghai

No.65, Yan An Road (West), Shanghai, 200040, China

中国上海市延安西路65号上海国际贵都大饭店办公楼 405 单元

Phone: +86-21-62489820

Fax: +86-21-62489821 
(C) 2011 The Author(s). Licensee IntechOpen. This chapter is distributed under the terms of the Creative Commons Attribution-NonCommercialShareAlike-3.0 License, which permits use, distribution and reproduction for non-commercial purposes, provided the original is properly cited and derivative works building on this content are distributed under the same license. 